\title{
Evaluating social infrastructure financial feasibility with life cycle costing methods
}

\author{
Imam Hagni Puspito ${ }^{1}$, Dian Perwitasari ${ }^{1}$, Ferry Munaf ${ }^{1}$, Jade Sjafrecia Petroceany ${ }^{1}$, \\ Herawati Zetha Rahman ${ }^{1}$, and Azaria Andreas ${ }^{1}$ \\ ${ }^{1}$ Department of Civil Engineering, Universitas Pancasila, Jakarta, Indonesia
}

\begin{abstract}
Social infrastructure is defining as a physical facility that has been build for local community provided by government, private, or even from other institution. Social infrastructure dedicated to a function of place, for a particular group of people or those with special needs. The social infrastructure concept that will be discussed in this research is Road Side Station, adopted from Japanesse Michinoeki. Similar with michinoeki, the road side station is predefined to organize service functions to road users, economic empowerment of local community, and part of incubation service for its surrounding area. Diffrent from highway's rest area that located at highway (toll road), the road side station will be located at nation road's side. In 2016, the Ministry of Public Works dan Housing developing a pilot project of road side station located in Tugu, Trenggalek District, East Java Province. According to that, this research is aim to analyze a model for evaluating social infrastructure financial feasibility, based on case study in Tugu's Road Side Station. This research used quantitative approach and then the Life Cycle Costing (LCC) methods will analyze and evaluate the financial modelling from construction phase to operating. With LCC methods, the percentage of Operation and Maintenance Cost (OM Cost) from all of the Capital Expenditure Cost (CAPEX Cost) can be calculate. Finally, the result shows that developing and operating Tugu's road side station through out its life cycle is financially feasible, according to the LCC analyze.
\end{abstract}

\section{Introduction}

Infrastructure plays an essential role in promoting economic growth and national competitiveness through equity of development, improvement of distribution channels and the provision of basic needs. Based on data from the Global Competitiveness Index 20162017 released by the World Economic Forum, Indonesia's competitiveness is ranked 41 out of 138 countries while infrastructure competitiveness is ranked at 60 [1]. This provides the basis for the Indonesian government to define infrastructure development as one of the priority targets which targets inter-regional connectivity improvements while achieving economic growth of 5.4 to 5.8 percent by 2019 [2].

Infrastructure development for the period 2015-2019 is estimated to require a budget of Rp. 4796 trillion [3]. While the budget capacity of the Government can only meet $41 \%$ of the total financing needs, the rest is expected to be financed by the private sector through 
the scheme of Public-Private Partnership (PPP). In the Presidential Regulation No. 38 of 2015 [4], 19 types of infrastructure sectors can be implemented under the scheme of PPP, and the sector covers the areas of economic infrastructure and social infrastructure.

The infrastructure development project involves some stakeholders as well as substantial investment. Therefore a comprehensive feasibility study is needed as a basis for the sustainable development policy of the infrastructure.

The feasibility of a commonly used infrastructure is a measure of economic feasibility and financial feasibility, due to the limited evaluation method, the feasibility of social infrastructure is often aligned with the two feasibility parameters used in the infrastructure of the economy. It is, therefore, necessary to develop an evaluation analysis of social-based infrastructure investments that can accommodate the sustainable goals of building a social infrastructure [5].

This study examines the financial feasibility evaluation of social infrastructure development based on the PPP while developing an attractive scheme for business entities to invest. Social infrastructure as the object of study in this research is a Roadside Station located in Trenggalek district, East Java.

\section{Literature review}

\subsection{Roadside station}

Social infrastructure is defined as a physical facility built for the community provided by either the government institution or the private sector. Investment in social infrastructure supports strengthening the health, welfare and economic welfare of the people. It plays an essential role in developing social capital, maintaining the quality of life, and improving community skills and resilience.

One form of social infrastructure is a roadside station. Roadside Station is a special purpose area built as a form of awareness to improve the safety of road users and supported by the development of local communities and information centers. The concept of the roadside station is adapted from the concept of Michinoeki, Japan which was established since 1993 and until now has managed to cope with the number of accidents as well as boost the economy of local communities through the implementation of Community-Driven Development (CDD).

The concept of roadside station applied is a resort around the strategic national road (similar with rest area) with various public facilities. In addition to functioning as a resting place, the roadside station also provides alternative destinations that will enhance the value of road infrastructure by utilizing the location, scenery, diversity of local products, artistry (products and performances), and infrastructure technology.

The roadside station benchmarking sourced from Michinoeki or roadside station in the following countries:

1) Japan, Michinoeki has three main functions, namely: resting place, information dissemination and building of territorial role including trade, education, and recreational activities and so forth. $80 \%$ of Michi-No-Eki facility management is done by the private sector, and the government is more focused on the service function to the community.

2) Vietnam, Michinoeki in Vietnam flourish based on the need for safety in the journey that requires a resting place for the rider. Regarding investment, Vietnam offers many things as a sweetener, including landscapes and scenery, authentic regional crafts, historical relics, traditional food including local art and culture that sells. 
3) China, Michinoeki is planned to accelerate backwardness to overcome current problems with all the challenges that China has through the existence of the communist party and its impact on Michinoeki's development and management. Michinoeki is located in one city in China named Hong Chun Zen, the facilities provided at Michinoeki Hong Chun Zen at least have: commercial area, place of product process area from the start of the process until end of packaging, tourism support facilities [6].

4) Africa, Michinoeki is seen as an appropriate infrastructure in addressing social issues, namely the spread of HIV/ AIDS along the Northern Corridor route is quite high. Michinoeki is also expected to contribute to reducing the number of pros through due to limited opportunities in the world of work with limited knowledge of the surrounding community, especially women (Nothern Corridor Roadside Station).

Based on the benchmarking mentioned above, it can be concluded the benefits of the roadside station such as empowerment, incubation area, social welfare, information exchange, knowledge and commodity, and safe driving.

\subsection{Roadside station in Trenggalek}

The Ministry of Public Works and Housing of Indonesia through the Regional Infrastructure Development Board since 2016 is completing the construction of a roadside station's pilot project located in Trenggalek.

The concept of roadside station applied is to form a resting place around the strategic national road for the road users who crossed the southern path of East Java. This roadside station is equipped with various public facilities.

The land used for the roadside station is planned for $3.5 \mathrm{Ha}$, with some facilities that can spoil motorists, such as vehicle parking area, green open space, ATM outlets, infrastructure development information center under The Ministry of Public Works and Housing especially concerning roads and Tugu Dam, floating dock, substation view, amphitheater, up to the local economic product storefront. With the roadside station, the road users feel a new sensation in the rest that can enjoy the results of crafts and agriculture and processed foods typical of local communities, and on the other hand, local communities benefit from the sale of products and services.

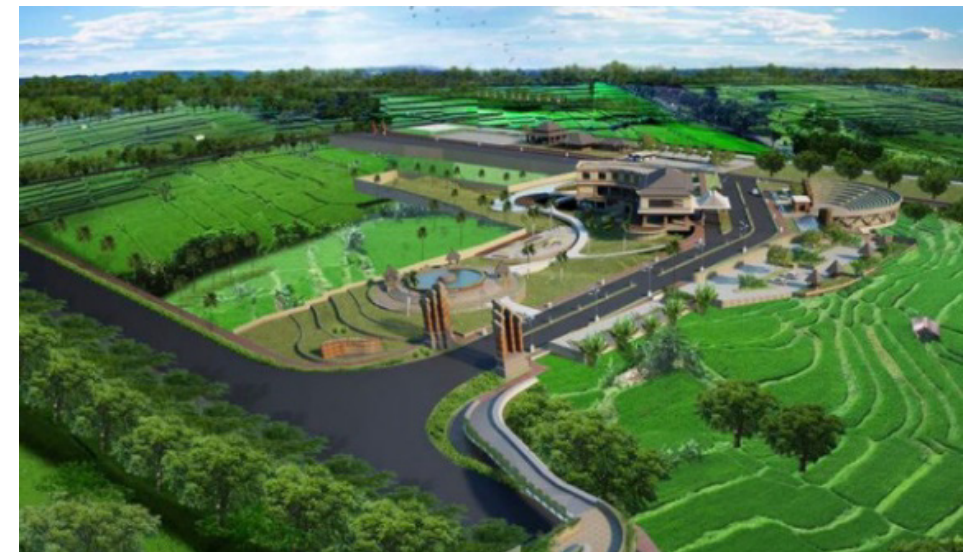

Fig. 1. Trenggalek roadside station.

Trenggalek was chosen for roadside station site, as it is one of the longest routes in the southern region of Java. Its position is on the edge of the national road TrenggalekPonorogo which is one of the interprovincial lanes as well as the axis connecting the south 
coast with the north coast of East Java through Madiun. The development will encourage regional development in the southern coastal area of Java. Smart Pavilion is expected to bring considerable benefits for the District of Trenggalek, as well as the surrounding area, ranging from Ponorogo, Pacitan, Tulungagung, Blitar until kediri.

\subsection{Life cycle costing}

Life cycle costing is a method that can be used to evaluate financial feasibility by analyzing the amount of investment to operating income of an infrastructure project. Methods The standard feasibility indicators commonly used in this evaluation include Net Present Value (NPV), Internal Rate of Return (IRR), and Payback Period.

All of these indicators will generally provide a comparative picture of the value of benefits and costs of each proposed alternative, but specifically, each indicator has different characteristics so that all indicators need to be checked to give a clearer picture of possible economic events and identified during the planning period.

1) Net Present Value (NPV)

2) Net Present Value is the difference between Present Value Benefit minus Present Value Cost. The NPV result of a project that is said to be financially feasible is that it yields a positive NPV value. In this case, all investments are eligible if NPV $>0$.

3) Internal Rate of Return (IRR)

4) Internal Rate of Return (IRR) is the magnitude of the interest rate when the value of $\mathrm{NPV}=0$. The IRR value of a project must be higher than the value of the prevailing interest rate or which is determined to be used in the project feasibility calculation. This value is used to obtain an interest rate where the net present value of expenditure (NPV) is zero. If the IRR value is higher than the applicable discount rate or MARR (Minimum Attractive Rate of Return), then the project has a financial advantage.

5) Return Period - Payback Period

6) The "Payback" period shows how long (within a few years) investments will be able to return. The "Payback" period shows the comparison between "initial investment" and the annual cash flow. Pay Back Period is identified when NPV is equal to zero, which means the payback period has been met.

\section{Methodology}

This study uses qualitative and quantitative methods, data collection on quantitative approaches is done to obtain the amount of cost and income components in some rest areas used as assumptions in life cycle costing analysis. Qualitative approaches are conducted with interviews to experts in area development, asset and financial management, and Cooperation of Government and Business Entities. Financial feasibility of smart bridge development is obtained by using Life Cycle Costing (LCC) analysis and simulation on some alternative of PPP scheme.

\section{Results and discussion}

The impact of the roadside station on economic activity can be quantified through the receipt obtained from various commercial activities that occur in the roadside station. The percentage of OM cost components and the average percentage of each facility is obtained from survey results in some rest areas in JABODETABEK area as a benchmarking, this value then becomes the basis of assumption used in LCC analysis (Table 1). 
Table 1. Basic assumption of financial analysis.

\begin{tabular}{|c|c|c|c|}
\hline \multicolumn{2}{|c|}{ Description } & Value & Unit price \\
\hline \multirow{2}{*}{ Financial } & Inflation & $4.5 \%$ & \\
\hline & Interest Rate & $12 \%$ & \\
\hline \multirow{3}{*}{$\begin{array}{l}\text { Operating and } \\
\text { Maintenance } \\
\text { (OM Cost) }\end{array}$} & Maintenance Cost & $20 \%$ & \\
\hline & Employee Cost & $30 \%$ & \\
\hline & Utilitas & $50 \%$ & \\
\hline \multirow{4}{*}{ Revenue } & Restaurant & $30 \%$ & Rp. 202,500 \\
\hline & Market & $30 \%$ & Rp. 270,000 \\
\hline & Lodging & $10 \%$ & Rp. 283,500 \\
\hline & Others & $30 \%$ & Rp. $8,322,750$ \\
\hline \multirow{3}{*}{$\begin{array}{c}\text { Demand }(3 \% \\
\text { growth rate per } \\
\text { year) }\end{array}$} & Pesimistic & $<5000$ orang & \\
\hline & Moderate & $<5000-10,000$ & \\
\hline & Optimistic & $>10,000$ & \\
\hline \multirow{3}{*}{ OM: IC Ratio } & Type I & High Ratio $=0.7$ & \\
\hline & Type II & Meoderate Ratio $=0.2$ & \\
\hline & Type III & Low Ratio $=0.1$ & \\
\hline
\end{tabular}

Table 2. LCC simulation scenario.

\begin{tabular}{|c|c|c|c|}
\hline \multirow{2}{*}{\multicolumn{2}{|c|}{ Scenario }} & \multicolumn{2}{|c|}{ Description } \\
\hline & & \multirow{2}{*}{$\begin{array}{c}\text { Demand } \\
\text { Pesimis }\end{array}$} & OM Cost \\
\hline \multirow{3}{*}{1} & A & & \multirow{3}{*}{ High } \\
\hline & B & Moderate & \\
\hline & $\mathrm{C}$ & Optimis & \\
\hline \multirow{3}{*}{2} & A & Pesimis & \multirow{3}{*}{ Moderate } \\
\hline & B & Moderate & \\
\hline & $\mathrm{C}$ & Optimis & \\
\hline \multirow{3}{*}{3} & A & Pesimis & \multirow{3}{*}{ Low } \\
\hline & B & Moderate & \\
\hline & $\mathrm{C}$ & Optimis & \\
\hline
\end{tabular}


The revenue prediction is calculated from the number of annual visitors, the average percentage of use of each facility and unit price per user. Furthermore, the OM cost reduces the revenue value to get the profit value of the roadside station. Revenue and profit is an essential parameter as an indicator of the success of roadside station planning.

Life Cycle Costing simulation is conducted on 9 scenarios, the scenario is arranged based on the level of demand and cost of $\mathrm{OM}$ as in the Table 2.

The result of life cycle costing analysis on nine scenarios using the basic assumptions above is shown in the Table 3. All scenarios 1 and 2 produce NPV and IRR negative, whereas in scenario three condition A with low OM cost and pessimistic demand also produce negative NPV and IRR. NPV and IRR positive occur in scenario 3 with conditions $\mathrm{B}$ and $\mathrm{C}$.

Table 4. The result of LCC Simulation.

\begin{tabular}{|c|c|c|}
\hline Scenario & Scheme & Simulation results \\
\hline 1A & Pessimistic Demand, High OM Cost & \multirow{2}{*}{ Negative NPV, Negative IRR } \\
\cline { 1 - 2 } 1B & Moderate Demand, High OM Cost & \\
\hline 1C & Optimistic Demand, High OM Cost & \multirow{2}{*}{ Negative NPV, Negative IRR } \\
\cline { 1 - 2 } 2A & Pessimistic Demand, Moderate OM Cost & \multirow{2}{*}{ Negative NPV, Negative IRR } \\
\hline 2B & Moderate Demand, Moderate OM Cost & \multirow{2}{*}{ Positive NPV, Positive IRR } \\
\cline { 1 - 2 } 2C & Optimistic Demand, Moderate OM Cost & \\
\hline 3A & Pessimistic Demand, Low OM Cost & \\
\cline { 1 - 2 } 3B & Moderate Demand, Low OM Cost & \\
\hline 3C & Optimistic Demand, Low OM Cost & \\
\hline
\end{tabular}

Table 3. Simulation of scenarios $3 b$ and $3 c$

\begin{tabular}{|c|c|c|}
\hline Scenario & Scheme & Simulation results \\
\hline 3B -1 & Pure OM Scheme & $\begin{array}{c}\text { The positive NPV score and IRR are above } \\
12 \% \text { in the } 25 \text { th year }\end{array}$ \\
\hline 3B - 2 & IC and OM schemes & $\begin{array}{c}\text { Positive NPV value with IRR above } 12 \%, \text { NPV } \\
\text { value obtained far below NPV Pure OM } \\
\text { Scheme }\end{array}$ \\
\hline 3B - 3 & IC scheme 50\% and OM & $\begin{array}{c}\text { Positive NPV value and IRR above } 12 \% \text { with } \\
\text { return time and IRR more attractive }\end{array}$ \\
\hline 3C - 1 & Pure OM Scheme & $\begin{array}{c}\text { NPV positive and IRR values above } 12 \% \text { below } \\
10 \text { years }\end{array}$ \\
\hline 3C - 2 & IC and OM schemes & $\begin{array}{c}\text { Positive NPV value with IRR above } 12 \%, \text { NPV } \\
\text { value obtained far below NPV Pure OM } \\
\text { Scheme }\end{array}$ \\
\hline 3C - 3 & IC scheme 50\% and OM & $\begin{array}{c}\text { Positive NPV value and IRR above } 12 \% \text { with } \\
\text { return time and IRR more attractive }\end{array}$ \\
\hline
\end{tabular}

The simulation results show that financing on a scheme whereby the government bears part or all of the financing, the NPV value and payback period is good, thus attracting business entities to invest. 


\section{Conclusions}

Trenggalek's roadside station as a form of social infrastructure is a pilot project that not only functions as a rest area but also provides alternative destinations that will enhance the value of road infrastructure by utilizing the location, scenery, diversity of local products, art (products and performances) and infrastructure technology. The PPP scheme to be implemented in Trenggalek's roadside station is aimed at the efficiency of the government budget, sharing of risk and improving service quality.

Based on the analysis of the feasibility of social infrastructure, it can be concluded that Trenggalek's roadside station is feasible to build, the scheme where the government bears the partial or overall cost of construction with low-cost assumption of OM with both optimistic and moderate demand, becomes an attractive option for business entities to invest in these smart bricks. However, the financing with the financing scheme options should also refer to the guidelines established by the government along with the distribution of risk, rights, and management obligations to provide proper management and services for riders, tourists, and the community around the roadside station.

\section{References}

1. K. Schwab, The Global Competitiveness Report 2016-2017 (World Economic Forum, Geneva, 2016)

2. A.M. Pratama, Sri Mulyani yakin tahun 2019 Ekonomi RI tumbuh hingga 5.8 Persen. Available at: https://ekonomi.kompas.com/read/2018/05/31/150600226/sri-mulyaniyakin-tahun-2019-ekonomi-ri-tumbuh-hingga-5-8-persen(2018)

3. Deputi Bidang Sarana dan Prasarana Kementrian PPN/BAPPENAS, Konektivitas infrastruktur wilayah dan antar wilayah (BAPPENAS, Jakarta, 2014)

4. Pemerintah Republik Indonesia, Peraturan Presiden Republik Indonesia no 38 tahun 2015 tentang Kerjasama Pemerintah dengan Badan Usaha Dalam Penyediaan Infrastruktur (Presiden Republik Indonesia, Jakarta, 2015)

5. A. Flockhart, Social Enterprise Journal 1, 1 (2005)

6. Anonymous. Technical Note B. Michinoeki pilot study in China. Available at: http://siteresources.worldbank.org/INTTRANSPORT/2145781097079596903/20281374/03_NoteB.pdf 